\title{
Digestion of protein in small and large intestine of the pig
}

\author{
By J. H. G. HOLMES,* H. S. BAYLEY ANd P. A. LEADBEATER \\ Department of Nutrition, University of Guelph, Guelph, Ontario, Canada \\ AND F. D. HORNEY \\ Ontario Veterinary College, University of Guelph, Guelph, Ontario, Canada
}

(Received 8 January 1973 - Accepted 26 March 1973)

\begin{abstract}
I. Six $45 \mathrm{~kg}$ pigs with re-entrant ileal cannulas were used in two $3 \times 3$ Latin-square design experiments to study the site of absorption of protein and amino acids. Semi-purified diets containing soya-bean meal (SBM), rapeseed meal (RSM) or no protein source (protein-free) were offered at the rate of $\mathrm{I} \mathrm{kg}$ dry matter/d.

2. Flow-rates of ileal contents for $24 \mathrm{~h}$ collection periods, corrected for recovery of marker, were 3135,3127 and $1243 \mathrm{ml}$ (SE 390) for SBM, RSM and protein-free diets respectively.

3. Amounts of dry matter digested in the small intestine were 730,669 and $809 \mathrm{~g} / \mathrm{d}$ for SBM, RSM and protein-free diets respectively, all values being significantly different $(P<0.00 \mathrm{I})$.

4. Nitrogen intakes were $32.6,29.9$ and $5.9 \mathrm{~g} / \mathrm{d}$, and amounts digested in the small intestine were $25.7,20.2$ and $\mathrm{r} \cdot 6 \mathrm{~g} / \mathrm{d}$ for SBM, RSM and protein-free diets respectively, all values being significantly different $\left(P<0^{\circ} \circ \mathrm{O}\right)$. Amounts digested in the large intestine were $2 \cdot 6,3.7$ and $0.7 \mathrm{~g} / \mathrm{d}$.

5. Total amino acid intakes and amounts collected at the ileum and in the faeces were $(\mathrm{g} / \mathrm{d})$ : SBM, I77, 24 and I8; RSM, I49, 28 and 22; protein-free 3, 9 and $\times 2$. Digestibility in the small intestine was higher for SBM than RSM for seventeen of the eighteen amino acids estimated. Greater quantities of arginine, methionine, cystine and tyrosine were voided in the faeces than passed through the ileal cannulas for pigs receiving the SBM and RSM diets. For those receiving the protein-free diet this was true for each amino acid except proline.

6. Significant differences were found between all diets in the concentration of some amino acids in ileal and faecal amino- $\mathrm{N}$, and endogenous protein secretions did not mask the differences between diets.

7. Differences in digestibility between SBM and RSM were greater at the ileum than in the faeces. Amino acid fermentation in the large intestine obscured or reduced differences between SBM and RSM.
\end{abstract}

In the stomach and small intestine protein is subjected to the effect of hydrolytic enzymes, which produce peptides and amino acids. In the caecum and colon of the pig all amino acids can be deaminated by micro-organisms to yield ammonia and various amines (Fauconneau \& Michel, I970), and can be incorporated into amino acids synthesized de novo. Hence the net disappearance of an amino acid from the digestive tract (i.e. difference between quantity of amino acid consumed and voided in faeces) does not necessarily represent absorption of that amount of amino acid (Cho \& Bayley, 1972). Net disappearance proximal to the caecum gives a minimum value for the apparent digestibility of an amino acid. Hydrolysis in the large intestine reduces, and synthesis increases, estimates of digestibility. The protein of rapeseed meal (RSM) has a lower feeding value for pigs than the protein of soya-bean meal (SBM), one reason for this difference is the lower apparent digestibility of most of its amino acids (Cho \& Bayley, I970). Cho \& Bayley (I972) found significant differences

* Present address: Beef Cattle Research Station, Erap, via LAE, Papua, New Guinea 
Table $\mathrm{x}$. Ingredients ( $\mathrm{g} / \mathrm{kg}$ ) of three semi-purified diets, based on soya-bean meal (SBM) or rapeseed meal $(R S M)$ as the sole source of protein, or protein-free, given to pigs

\begin{tabular}{|c|c|c|c|}
\hline Ingredient & SBM & RSM & Protein-free \\
\hline $\mathrm{SBM}\left(48_{3} \mathrm{~g}\right.$ crude protein $\left./ \mathrm{kg}\right)$ & 306 & - & - \\
\hline $\operatorname{RSM}(345 \mathrm{~g}$ crude protein $/ \mathrm{kg}) *$ & - & 435 & 一 \\
\hline Maize starch $\uparrow$ & 344 & 270 & 600 \\
\hline Maize sugarf & 200 & 200 & 200 \\
\hline Cellulose§ & 95 & 40 & 145 \\
\hline Ground limestone & I5 & $i_{5}$ & 15 \\
\hline Calcium phosphate & 20 & 20 & 20 \\
\hline Iodized salt & IO & 10 & Io \\
\hline Vitamin-mineral supplement\| & Io & 10 & Io \\
\hline
\end{tabular}

in the concentrations of several amino acids between samples of ileal digesta and faeces from slaughtered animals fed on semi-purified diets containing either RSM or SBM. Using polyethylene glycol as a marker, they showed that, in pigs given SBM diets, $45 \%$ of the nitrogen and $63 \%$ of the amino acids found in ileal contents were not recoverable from faeces. Holmes, Bayley \& Horney (1973) analysed $24 \mathrm{~h}$ collections of ileal contents from pigs fitted with re-entrant cannulas and found digestibility ratios of $0.43^{-0.75}$ for $\mathrm{N}$ in the large intestine when the diet contained $750 \mathrm{~g}$ maize, $200 \mathrm{~g}$ SBM and $50 \mathrm{~g}$ minerals $/ \mathrm{kg}$.

In the present study the total amounts of amino acids passing from the small intestine were compared with the amounts lost in the faeces; SBM and RSM were used as the sole sources of protein in semi-purified diets, and total collections of ileal contents were made, using pigs fitted with re-entrant cannulas, in a Latin-square design experiment. A protein-free ration was also given, to obtain an estimate of endogenous $\mathrm{N}$ flow at the ileum.

\section{EXPERIMENTAL}

\section{Animals}

Six Yorkshire Duroc castrated male pigs of about $45 \mathrm{~kg}$ live weight, fitted with re-entrant ileal cannulas placed within $250 \mathrm{~mm}$ of the ileal-caecal orifice, were housed in metabolism cages and fed at 09.00 hours and 16.00 hours. Water was available at all times, but intake was not recorded.

\section{Diet}

The composition and proximate analysis of the three diets is shown in Table $\mathrm{I}$ and the amino acid composition of the diets is shown in Table 2. Chromic oxide $(3 \mathrm{~g} / \mathrm{kg})$ was added to the diets given in Expt I. A commercial sample of soya-bean meal was obtained which had been adequately processed to destroy the trypsin inhibitors. The rapeseed meal was manufactured from a recently introduced cultivar of Brassica napus 
Table 2. Crude protein and amino acid contents $\dagger$ of diets for pigs with soya-bean meal $(S B M)$ or rapeseed meal $(R S M)$ as the sole source of protein, or protein-free

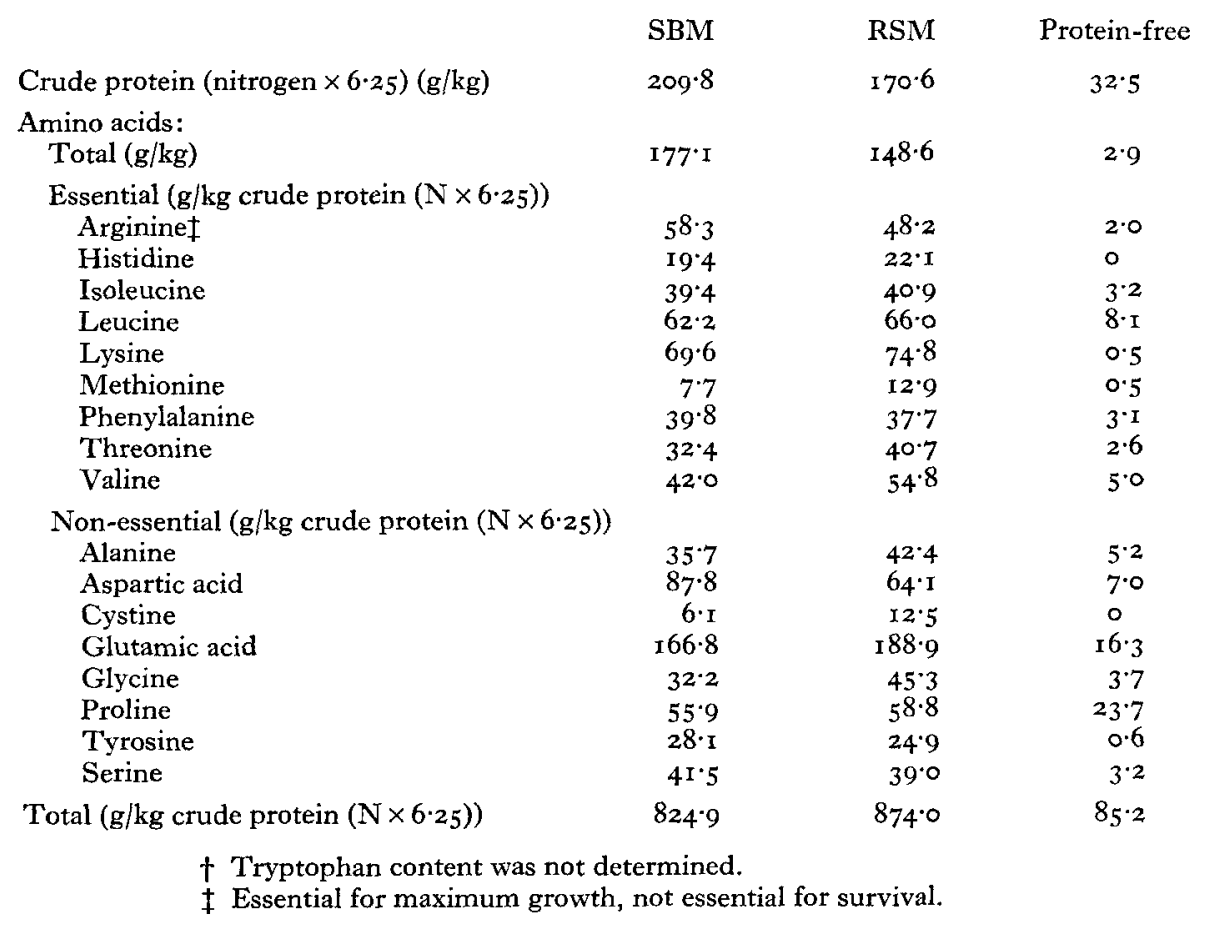

Table 3. Mean uptake of dry matter (DM) and nitrogen in the small intestine (SI) and large intestine $(L I)$ of six pigs and two pigs respectively, each weighing $45 \mathrm{~kg}$, given semi-purified diets with soya-bean meal (SBM) or rapeseed meal (RSM) as the sole source of protein, or protein-free

\begin{tabular}{|c|c|c|c|c|c|c|c|}
\hline \multirow[b]{2}{*}{ Diet } & \multirow[b]{2}{*}{$\begin{array}{l}\text { Intake } \\
(\mathrm{g} / \mathrm{d})\end{array}$} & \multicolumn{2}{|c|}{ SI } & \multicolumn{2}{|c|}{ LI } & \multicolumn{2}{|c|}{ Total (SI + LI) } \\
\hline & & $\begin{array}{l}\text { Digestibility } \\
\text { ratio }\end{array}$ & $\begin{array}{c}\text { Amount } \\
\text { absorbed } \\
(\mathrm{g} / \mathrm{d})\end{array}$ & $\begin{array}{l}\text { Digestibility } \\
\text { ratio }\end{array}$ & $\begin{array}{c}\text { Amount } \\
\text { absorbed } \\
(\mathrm{g} / \mathrm{d})\end{array}$ & $\begin{array}{l}\text { Digestibility } \\
\text { ratio }\end{array}$ & $\begin{array}{l}\text { Amount } \\
\text { absorbed } \\
(\mathrm{g} / \mathrm{d})\end{array}$ \\
\hline \multicolumn{8}{|c|}{ DM } \\
\hline $\begin{array}{l}\text { SBM } \\
\text { RSM } \\
\text { Protein-free }\end{array}$ & $\begin{array}{l}\text { I0I } 8.6 \\
\text { I0I } 7.2 \\
\text { I000.7 }\end{array}$ & $\begin{array}{l}0.717^{b} \\
0.658^{a} \\
0.808^{c}\end{array}$ & $\begin{array}{l}730 \cdot 3^{\mathrm{b}} \\
669 \cdot 2^{\mathrm{a}} \\
808 \cdot 7^{\mathrm{c}}\end{array}$ & $\begin{array}{l}0.456 \\
0.410 \\
0.302\end{array}$ & $\begin{array}{r}131 \cdot 4 \\
142 \cdot 5 \\
57 \cdot 9\end{array}$ & $\begin{array}{l}0.846 \\
0.798 \\
0.866\end{array}$ & $\begin{array}{l}86 r \cdot 7 \\
8 I I \cdot 7 \\
866 \cdot 6\end{array}$ \\
\hline \multicolumn{7}{|c|}{$\mathrm{N}$} & \\
\hline $\begin{array}{l}\text { SBM } \\
\text { RSM } \\
\text { Protein-free }\end{array}$ & $\begin{array}{r}32 \cdot 60 \\
29 \cdot 86 \\
5.88\end{array}$ & $\begin{array}{l}0.799^{a} \\
0.677^{a} \\
0.287^{b}\end{array}$ & $\begin{array}{r}25.67^{2} \\
20.2 I^{b} \\
I .6 I^{c}\end{array}$ & $\begin{array}{l}0.380 \\
0.388 \\
0.157\end{array}$ & $\begin{array}{l}2 \cdot 63 \\
3.74 \\
0.67\end{array}$ & $\begin{array}{l}0.868 \\
0.802 \\
0.388\end{array}$ & $\begin{array}{r}28 \cdot 30 \\
23 \cdot 95 \\
2 \cdot 28\end{array}$ \\
\hline SE & & $0.059^{* *}$ & $0.5 \mathrm{I} * *$ & & & & \\
\hline
\end{tabular}


('Span') and had a low erucic acid content. It was prepared by the 'pre-press solvent' process, and was part of a batch produced for experimental purposes. Each diet was given for I week before collections were made. Each feed contained $550 \mathrm{~g}$ air-dried material, giving a daily intake of about $1000 \mathrm{~g}$ dry matter (DM) (Table 3).

\section{Collection of ileal contents}

The equipment and procedure for $24 \mathrm{~h}$ collections were as described by Holmes et al. (1973). Faecal samples were collected on the day before the ileal collections to allow calculation of digestibility from chromic oxide recovery. Faecal samples from one animal in Expt I were lost, therefore results were available for only two pigs.

\section{Analytical methods}

DM was determined by freeze-drying the samples. $\mathrm{N}$ was measured by the Kjeldahl method using copper sulphate as a catalyst. Chromic oxide was measured using an atomic absorption spectrophotometer after digestion of the samples with nitric and perchloric acids. Amino acids were determined by ion-exchange chromatography (TSM Amino Acid AutoAnalyzer with retrofit modification, using a column of Technicon Type C-3 chromabeads; Technicon Inc., Tarrytown, New York).

\section{Design and statistical methods}

Since chromic oxide has been found to interfere with the function of the Technicon Amino Acid AutoAnalyzer, two $3 \times 3$ Latin-square design experiments were done. In Expt $\mathrm{r}$ the diet contained chromic oxide to allow correction of flow rates to $100 \%$ recovery. In Expt 2, three pigs were given the same three diets without chromic oxide. Flow-rates in Expt 2 were corrected using the mean recovery of chromic oxide measured in $24 \mathrm{~h}$ total collections made I and 2 weeks before and I week after this experiment. Samples from Expt 2 were used for amino acid analysis. Digestibility in the small intestine was calculated as the difference between the dietary intake and the amount leaving the ileum expressed as a ratio of the intake, and thus contrasted the uptake of amino acids as such from the small intestine with the net disappearance (uptake of amino acid plus microbial loss) measured as apparent digestibility by conventional faecal analysis. The results were analysed by the methods of Federer (1955) for replicated Latin-square design experiments since there were no significant differences between experiments in corrected ileal flow-rates or absorption of DM and $\mathrm{N}$ proximal to the cannulas, although there was a difference between experiments in the method used to correct flow-rates to $100 \%$ recovery of chromic oxide. The nonsignificant interaction of experiment $v$. treatments was pooled with error within experiments to give an error term with six degrees of freedom (Steele \& Torrie, 1960). In no instance in these experiments was there a significant difference between weeks, pigs or experiments for results based on ileal collections. 
Table 4. Amino acid content (mg/g total amino acids) of samples taken from ileum and of the faeces of pigs given semi-purified diets with soya-bean meal (SBM) or rapeseed meal $(R S M)$ as the sole source of protein, or protein-free

(Mean values with their standard errors for three pigs)

\begin{tabular}{|c|c|c|c|c|c|c|c|c|}
\hline & & Ileal c & ontents & & & $\mathrm{Fa}$ & eces & \\
\hline & SBM & RSM & $\begin{array}{l}\text { Protein- } \\
\text { free }\end{array}$ & $\mathrm{SE}$ & SBM & RSM & $\begin{array}{l}\text { Protein- } \\
\text { free }\end{array}$ & $\mathrm{SE}$ \\
\hline Essential amino acids & & & & & & & & \\
\hline Arginine & $34 \cdot 1$ & $3^{8 \cdot 4}$ & $33 \cdot 7$ & $I \cdot 2$ & $947^{\mathrm{a}}$ & $100 \cdot 7^{b}$ & 115.9 & 0.9 \\
\hline Histidine & $5 \cdot 4$ & 9.5 & 37 & $2 \cdot 2$ & $7 \cdot 5$ & $11 \times$ & $4 \cdot 4$ & $1 \cdot 3$ \\
\hline Isoleucine & $47^{\cdot} 6^{a}$ & $50.0^{\circ}$ & $30 \cdot 0^{b}$ & $2 \cdot 6$ & $42 \cdot 5$ & $41 \cdot 9$ & $42 \cdot 1$ & 0.7 \\
\hline Leucine & $72 \cdot 5$ & $68 \cdot 0^{-}$ & $47 \cdot 1$ & $4 \cdot 8$ & $8 x \cdot 1$ & $82-1$ & 747 & $3 \cdot 2$ \\
\hline Lysine & $58 \cdot 0^{\mathrm{a}}$ & $8 \mathrm{I} \cdot 7^{b}$ & $42 \cdot 0^{2}$ & 3.0 & $66 \cdot 5$ & $7 I \cdot I$ & $79 \cdot 1$ & $8 \cdot 8$ \\
\hline Methionine & $2 \cdot 2$ & $5 \cdot 5$ & $3 \cdot 2$ & $1 \cdot 3$ & $\times 9.2$ & $19 \cdot 3$ & I6. 5 & 0.9 \\
\hline Phenylalanine & $42 \cdot 6^{a}$ & $3^{6 \cdot 8^{a b}}$ & $26 \cdot 0^{b}$ & $2 \cdot 0$ & $44 \cdot 6$ & $43 \cdot 4$ & $44 \cdot I$ & 0.8 \\
\hline Threonine & $5 I \cdot 8$ & $65 \cdot 4$ & $47 \cdot 9$ & $4 \cdot I$ & $6 I \cdot 1$ & $62 \cdot 5$ & $59 \cdot 8$ & $I \cdot 2$ \\
\hline Valine & $57 \cdot 9$ & 83.8 & $43 \% 4$ & $7 \cdot 6$ & $49 \cdot x$ & $55 \cdot 5$ & $48 \cdot 4$ & $I \cdot 2 *$ \\
\hline Non-essential amino & & & & & & & & \\
\hline Alanine & 60.9 & $55 \cdot 3$ & 53.7 & $4 \cdot I$ & $7 x \cdot 8^{2}$ & $6 I \cdot 2^{b}$ & $66 \cdot 8^{\mathrm{ab}}$ & $x \cdot 3$ \\
\hline Aspartic acid & $102 \cdot 7^{\mathrm{a}}$ & $9 x \cdot 7^{a}$ & $65.7^{\mathrm{b}}$ & $3 \cdot 1$ & $109.5^{\mathrm{a}}$ & $97 \cdot I^{b}$ & $107 \cdot 1^{a}$ & $\mathrm{r} \cdot \mathrm{s}$ \\
\hline Cystine & $3 \cdot 9$ & $8 \cdot 3$ & $6 \cdot 3$ & $I \cdot 9$ & $20 \cdot 9$ & 22.9 & $20 \cdot 5$ & $x \cdot 4$ \\
\hline Glutamic acid & $155 \%$ & $144 \cdot 6$ & $92 \cdot 3$ & $10 \cdot 4^{*}$ & $145^{\circ} \mathrm{O}$ & $129^{\circ} \mathrm{I}$ & $133 \cdot 3$ & $2 \cdot 4^{*}$ \\
\hline Glycine & 82.0 & $7 x \cdot 2$ & $88 \cdot 6$ & 8.0 & $63 \cdot 2$ & $68 \cdot 0$ & $63 \cdot 1$ & $2 \cdot 3$ \\
\hline Proline & $143 \cdot 9$ & 104.4 & $35 \times \cdot 5$ & $36 \cdot 6 *$ & $3^{6 \cdot 8}$ & $5 \mathrm{I} \cdot 8$ & $5 \mathrm{r} \cdot 8$ & $13 \cdot 4$ \\
\hline Tyrosine & 27.7 & $29 \cdot 5$ & 20.4 & $2 \cdot 8$ & $43 \cdot 6$ & $40 \cdot 0$ & $40 \cdot 6$ & $0.6 *$ \\
\hline Serine & 50.9 & 55.6 & 44.7 & $2 \cdot 4$ & $59 \cdot 3$ & $59 \cdot 9$ & $57 \cdot 5$ & $2 \cdot 2$ \\
\hline $\begin{array}{l}\text { Total amino acids ( } \mathrm{n} \\
\text { crude protein }\end{array}$ & & & & & & & & \\
\hline$($ nitrogen $\times 6 \cdot 25))$ & 610 & $57 x$ & 515 & 60 & 729 & 542 & 770 & $5^{\circ}$ \\
\hline $\begin{array}{l}\text { Crude protein }(\mathrm{N} \times 6 . \\
(\mathrm{mg} / \mathrm{g} \text { dry matter })\end{array}$ & $14 I^{\prime} \cdot 2^{b}$ & $I 70 \cdot I^{a}$ & $115^{\circ} 2^{\mathrm{c}}$ & $2 \cdot 8$ & I 57.5 & 194.2 & $123 \cdot 2$ & $x 6 \cdot 7$ \\
\hline
\end{tabular}

\section{RESULTS}

The flow-rates of ileal contents corrected for $100 \%$ recovery of chromic oxide were, for the three diets: SBM 3135, RSM 3127 and protein-free $1243 \mathrm{ml} / 24 \mathrm{~h}$ (SE 390). The flow-rate for the protein-free diet was significantly less than those for the other two diets $(P<0.01)$. All digestibilities reported are apparent digestibilities.

Intestinal digestibility of DM proximal to the ileal cannulas (Table 3 ) differed significantly between each diet. Estimates of total digestibility were based on two pigs/diet and were not compared statistically. In this study there were no significant effects of 'pigs' or 'weeks' on ileal digestibilities, and in another study using the same pigs which ended I week before the start of the present experiment there were no differences between 'weeks' (Holmes et al. 1973). In this previous study using these pigs differences in digestibility of the magnitude of the difference between those for RSM and the other diets were highly significant. Conventional digestibility trials have also shown that the total digestibility of the SBM and RSM diets differ significantly (Cho \& Bayley, r970). 
Table 5. Amounts of amino acids ingested, collected at the ileum and present in faeces $(g / d)$ for pigs fitted with re-entrant ileal cannulas, given semi-purified diets with soya-bean meal $(S B M)$ or rapeseed meal $(R S M)$ as the sole source of protein, or protein-free

(Mean values for three pigs)

\begin{tabular}{|c|c|c|c|c|c|c|c|c|c|}
\hline \multirow[b]{2}{*}{ Amino acid } & \multicolumn{3}{|c|}{ SBM } & \multicolumn{3}{|c|}{ RSM } & \multicolumn{3}{|c|}{ Protein-free } \\
\hline & Intake & $\begin{array}{l}\text { Collected } \\
\text { at ileum }\end{array}$ & $\begin{array}{c}\text { In } \\
\text { faeces }\end{array}$ & Intake & $\begin{array}{l}\text { Collected } \\
\text { at ileum }\end{array}$ & $\begin{array}{c}\text { In } \\
\text { faeces }\end{array}$ & Intake & $\begin{array}{l}\text { Collected } \\
\text { at ileum }\end{array}$ & $\begin{array}{c}\text { In } \\
\text { faeces }\end{array}$ \\
\hline \multicolumn{10}{|l|}{ Essential: } \\
\hline Arginine & $12 \cdot 53$ & $0.8 \mathrm{I}$ & $I \cdot 65$ & $8 \cdot 34$ & I'IO & $2 \cdot 18$ & 0.07 & 0.31 & $x \cdot 37$ \\
\hline Histidine & $4 \cdot 17$ & 0.12 & 0.15 & $3 \cdot 82$ & 0.29 & 0.24 & - & 0.03 & 0.06 \\
\hline Isoleucine & $8 \cdot 46$ & $I \cdot I 4$ & 0.76 & 7.09 & $I \cdot 43$ & 0.91 & $0.1 \mathbf{I}$ & 0.26 & 0.51 \\
\hline Leucine & 13.35 & I. 74 & $I \cdot 46$ & $I I \cdot 43$ & $\mathrm{I} \cdot 95$ & $I \cdot 79$ & $0.2,8$ & $0.4 \mathrm{I}$ & 0.89 \\
\hline Lysine & $14: 95$ & $1 \cdot 39$ & $\mathrm{I} \cdot 2 \mathrm{I}$ & 12.95 & $2 \cdot 43$ & $\mathrm{I} \cdot 55$ & 0.02 & 0.36 & 0.92 \\
\hline Methionine & $\begin{array}{r}4.65 \\
1.65\end{array}$ & 0.05 & 0.35 & $2 \cdot 23$ & 0.17 & 0.42 & 0.02 & 0.03 & 0.20 \\
\hline Phenylalanine & $8 \cdot 55$ & I.03 & 0.79 & $6 \cdot 52$ & $\mathrm{I} \cdot 06$ & 0.95 & 0.11 & 0.22 & 0.55 \\
\hline Threonine & $\begin{array}{l}6.95 \\
6.96\end{array}$ & $I \cdot 24$ & $1 \circ 99$ & 7.04 & $\mathrm{I} \cdot 86$ & I. 27 & 0.09 & 0.42 & 0.72 \\
\hline Valine & $9.0 \mathrm{I}$ & I.39 & 0.88 & 9.50 & $2 \cdot 50$ & $1 \cdot 2 I$ & 0.17 & $0.3^{8}$ & 0.59 \\
\hline \multicolumn{10}{|l|}{ Non-essential: } \\
\hline Alanine & 7.66 & $I \cdot 45$ & $I \cdot 29$ & $7 \cdot 35$ & $I \cdot 57$ & I'34 & 0.18 & 0.48 & 0.82 \\
\hline Aspartic acid & $18 \cdot 85$ & $2 \cdot 45$ & I.97 & II'II & $2 \cdot 54$ & $2 \cdot 12$ & 0.24 & 0.58 & $I \cdot 30$ \\
\hline Cystine & $I \cdot 32$ & 0.05 & 0.36 & $2 \cdot 17$ & 0.25 & 0.50 & - & 0.05 & 0.25 \\
\hline Glutamic acid & $35 \cdot 82$ & 3.71 & $2 \cdot 62$ & $32 \cdot 71$ & $4 \cdot 18$ & $2 \cdot 63$ & 0.56 & 0.80 & $1 \cdot 62$ \\
\hline Glycine & 6.90 & $\mathrm{I} \cdot 97$ & 0.93 & 7.85 & 2.05 & $1 \cdot 38$ & 0.13 & 0.82 & 0.78 \\
\hline Proline & $12 \cdot 00$ & $3 \cdot 36$ & 0.31 & 10.18 & $2 \cdot 95$ & 0.52 & $0.8 \mathrm{I}$ & $3 \cdot 3 I$ & 0.34 \\
\hline Tyrosine & 6.02 & 0.67 & 0.79 & $4 \cdot 31$ & 0.86 & 0.87 & 0.02 & 0.18 & 0.50 \\
\hline Serine & 8.90 & $I \cdot 2 I$ & I.07 & 6.67 & $I \cdot 59$ & $I \cdot 22$ & $0 \cdot 1 I$ & 0.40 & $0.7 x$ \\
\hline Total & $177 \cdot 12$ & $23 \cdot 83$ & $18 \cdot 33$ & 148.63 & $27 \cdot 6 \mathrm{r}$ & $2 I \cdot 63$ & 2.90 & 9.01 & I $2 \cdot 15$ \\
\hline
\end{tabular}

The apparent digestibility ratio of the $\mathrm{N}(5.88 \mathrm{~g} / \mathrm{kg})$ in the protein-free diet was significantly less than that of the $N$ (approximately $3 \circ \mathrm{g} / \mathrm{kg}$ ) in either the SBM or the RSM diet. The amounts of $\mathrm{N}$ given and collected with this diet were much smaller than the amounts with the SBM and RSM diets, so that normal variations in the amount collected caused proportionately much wider variations in estimates of digestibility for this diet than for the two oilseed-meal diets. This resulted in a large standard error for digestibility. The amounts of $\mathrm{N}$ absorbed or collected differed highly significantly between all three diets.

Less than $10 \%$ of the $\mathrm{N}$ in the protein-free diet was amino- $\mathrm{N}$ (Table 2), whereas the $\mathrm{N}$ in ileal contents was mainly $\mathrm{NH}_{2}-\mathrm{N}$ ('Table 4 ). The term apparent digestibility for this diet is thus somewhat meaningless. The amino acid composition of the ileal and faecal samples are presented in Table 4. The most striking result was the large amount of proline in samples from animals given the protein-free diet, approximately one-third of the total amino acid content. The intakes of amino acids and the quantities collected at the ileum and in the faeces are presented in Table 5. Proline was the only amino acid for which endogenous amino acid collected from pigs given the protein-free diet was equal to that collected from pigs given RSM or SBM. For most of the amino acids the amounts collected from the pigs given the 'protein-free' diet was less than one-quarter of the amounts collected from the pigs given the SBM and RSM diets. The amino acid flow associated with the protein-free diet would not 
Table 6. Digestibility ratios for amino acids in the small intestine of pigs given semipurified diets in which the sole source of protein was soya-bean meal (SBM) or rapeseed meal $(R S M)$

(Mean values for three pigs)

$\begin{array}{lll}\text { Amino acid } & \text { SBM } & \text { RSM } \\ \text { Essential: } & & \\ \text { Arginine } & 0.935 & 0.868 \\ \text { Histidine } & 0.970 & 0.925 \\ \text { Isoleucine } & 0.865 & 0.798 \\ \text { Leucine } & 0.870 & 0.829 \\ \text { Lysine } & 0.907 & 0.813 \\ \text { Methionine } & 0.967 & 0.925 \\ \text { Phenylalanine } & 0.879 & 0.838 \\ \text { Threonine } & 0.822 & 0.735 \\ \text { Valine } & 0.846 & 0.737 \\ \text { Non-essential: } & & \\ \text { Alanine } & 0.811 & 0.786 \\ \text { Aspartic acid } & 0.870 & 0.772 \\ \text { Cystine } & 0.923 & 0.886 \\ \text { Glutamic acid } & 0.897 & 0.877 \\ \text { Glycine } & 0.716 & 0.730 \\ \text { Proline } & 0.718 & 0.710 \\ \text { Tyrosine } & 0.886 & 0.801 \\ \text { Serine } & 0.863 & 0.762 \\ \text { Total } & 0.865 & 0.810\end{array}$

be equal to the endogenous flow of protein associated with the other two diets unless alimentary secretions with the three diets were the same. As the latter situation was not probable, the amino acid flow associated with RSM and SBM diets was not corrected for the flow with the protein-free diet. For the latter, the amount of each amino acid collected exceeded the intake, and, for total amino acids, was three times greater than the amount given. Digestibility ratios for the individual amino acids of the protein-free diet are not presented, but with the exception of glycine, those for the SBM diet were greater than those for RSM diet (Table 6). The lowest apparent digestibility was that of proline.

The amounts of amino acids in the faeces (Table 5) were calculated from the values for mean DM digestibility ratios determined in Expt $\mathrm{I}$ and the amino acid composition of the samples determined in Expt 2 (Table 4), therefore statistical analyses were not done for these composite results. In pigs given SBM and RSM diets, more arginine, methionine, cystine and tyrosine were collected in the faeces than at the ileum, suggesting that there was synthesis of these amino acids in the large intestine. For the protein-free diet, more of each amino acid except glycine and proline was collected in the faeces than at the ileum and the total amino acid content of the faeces was $3 \mathrm{~g}$ greater than that of the ileal contents (Table 5).

\section{DISCUSSION}

Flow-rates of digesta in animals given the SBM and RSM diets were the same and were very similar to those for maize-SBM diets (Holmes et al. 1973), about $31 / \mathrm{d}$, while that for the protein-free diet was less than half this value, but DM contents were 
Table 7. Amino acid disappearance in the large intestine $(L I)$ and total digestibility ratio for amino acids in pigs given semi-purified diets in which the sole source of protein was soya-bean meal (SBM) or rapeseed meal (RSM)

(Mean values for three pigs)

\begin{tabular}{|c|c|c|c|c|}
\hline \multirow[b]{2}{*}{ Amino acid } & \multicolumn{2}{|c|}{ SBMI } & \multicolumn{2}{|c|}{ RSM } \\
\hline & LI & Total & LI & Total \\
\hline $\begin{array}{l}\text { Essential: } \\
\text { Arginine } \\
\text { Histidine } \\
\text { Isoleucine } \\
\text { Leucine } \\
\text { Lysine } \\
\text { Methionine } \\
\text { Phenylalanine } \\
\text { Threonine } \\
\text { Valine }\end{array}$ & $\begin{array}{l}- \\
- \\
0.333 \\
0.161 \\
0.125 \\
- \\
0.229 \\
0.117 \\
0.368\end{array}$ & $\begin{array}{l}0.869 \\
0.964 \\
0.910 \\
0.891 \\
0.919 \\
0.791 \\
0.908 \\
0.843 \\
0.903\end{array}$ & $\begin{array}{l}- \\
0.157 \\
0.363 \\
0.086 \\
0.361 \\
- \\
0.104 \\
0.318 \\
0.516\end{array}$ & $\begin{array}{l}0.738 \\
0.937 \\
0.871 \\
0.844 \\
0.880 \\
0.810 \\
0.854 \\
0.819 \\
0.873\end{array}$ \\
\hline $\begin{array}{l}\text { Non-essential: } \\
\text { Alanine } \\
\text { Aspartic acid } \\
\text { Cystine } \\
\text { Glutamic acid } \\
\text { Glycine } \\
\text { Proline } \\
\text { Tyrosine } \\
\text { Serine }\end{array}$ & $\begin{array}{l}0.109 \\
0.195 \\
- \\
0.295 \\
0.528 \\
0.908 \\
\frac{0.125}{-}\end{array}$ & $\begin{array}{l}0.83 \mathrm{I} \\
0.895 \\
0.73 \mathrm{I} \\
0.927 \\
0.865 \\
0.974 \\
0.869 \\
0.878\end{array}$ & $\begin{array}{c}0.146 \\
0.165 \\
- \\
0.371 \\
0.324 \\
0.824 \\
- \\
0.234\end{array}$ & $\begin{array}{l}0.817 \\
0.809 \\
0.770 \\
0.920 \\
0.824 \\
0.949 \\
0.797 \\
0.818\end{array}$ \\
\hline Total & 0.231 & 0.896 & 0.217 & 0.854 \\
\hline
\end{tabular}

$80-\mathrm{I} \mathrm{O} / \mathrm{g} / \mathrm{kg}$ for the SBM and RSM diets and $153 \mathrm{~g} / \mathrm{kg}$ for the protein-free diet. The lower flow-rate and higher DM content of digesta with the protein-free diet may have been due to the absence of protein, which in itself or as peptides, is a major stimulus to gastric and pancreatic secretion.

Total digestibility ratios for DM and $\mathrm{N}$ were similar to those reported by Cho \& Bayley (1970, 1972), who found that the RSM diet was less digestible than the SBM diet. As the amounts of starch and cellulose were adjusted so that the diets had identical $\mathrm{N}$ and fibre contents, no conclusions could be drawn from the DM digestibilities of the SBM and RSM diets. However, the digestibility ratios for the SBM diet were higher than those for RSM in each section of the gut particularly in the small intestine (cf. Holmes et al. 1973). The disappearance of DM from the small intestine was greatest for the 'protein-free' diet, but from the large intestine it was least. In animals given this diet $192 \mathrm{~g}$ of material/d entered the large intestine, and this would have included I $45 \mathrm{~g}$ cellulose unless digestion of cellulose occurred in the small intestine. Farrell \& Johnson (1972) found that the digestibility ratio of cellulose (Solka-Floc) by pigs was between 0.27 and 0.37 but a shortage of $\mathrm{N}$ in the diet used in our experiment might have limited cellulose fermentation to even lower values.

Although the difference between the $\mathrm{N}$ digestibility ratio for SBM and that for RSM in the small intestine was 0.122 , the difference between the values for digestibility ratios was only 0.066 . This suggests that fermentation of nitrogenous material and absorption of end-products of fermentation, such as ammonia, obscured the magnitude 
of the difference in $\mathrm{N}$ uptake from the small intestine which is probably the only section of the gut from which amino acids can be absorbed.

There have been several reports of the use of ileal sampling to study amino acid availability, but the relevance of such studies to measurements of the nutritional value of proteins remains controversial (Bayley, Cho \& Holmes, 1974). Cho \& Bayley (1972) reported that many of the differences in the amino acid contents of SBM and RSM were reflected in the amino acid composition of the contents of the intestine of pigs when samples were collected $2.5 \mathrm{~h}$ after a meal. Nasset \& Ju (I96I) using rats and dogs and Twombly \& Meyer (I96I) using rats demonstrated that the contribution of endogenous $\mathrm{N}$ to $\mathrm{N}$ in the contents of the small intestine was much greater than the contribution of exogenous (i.e. dietary) $\mathrm{N}$, so that the endogenous amino acids obscured the amino acid patterns of the diet. However, the results in Table 4 show that the amino acid content of the material reaching the ileum, after completion of absorption of amino acid, differed greatly from the composition of the digesta in animals given the 'protein-free' diet.

The difference between our results and those of other workers may have been due to the difference in the species used. Twombly \& Meyer (I96r), Nasset, Schwartz \& Weiss (1955), Bergen \& Purser (1968) and Nasset \& Ju (1961) all used rats in their studies and their conclusions were the same although the protein sources used were different; casein and zein (Nasset et al. I955), casein, bacterial and protozoal protein (Bergen \& Purser, 1968) and egg protein (Twombly \& Meyer, 1961), and the availability and digestibility of the protein varied. Also the difference in the method of collection of the samples does not explain the differences between the results for pigs and rats. In rats the total contents of the small intestine were collected. However, Cho \& Bayley (1972) found that differences in amino acid patterns between diet and gut contents were often consistent throughout the entire intestinal tract, while Nasset $\& \mathrm{Ju}$ ( I $96 \mathrm{r}$ ) using dogs found a similar pattern to that in rats. Apparently the amount of endogenous protein secreted relative to dietary protein intake is much less in the pig than in the dog or the rat.

Crompton \& Nesheim (1969) found that amino acid patterns of intestinal contents of ducks reflected the amino acid pattern of the diet, supporting the hypothesis that the degree of dilution of exogenous protein by endogenous protein, reported by Nasset \& Ju (196r) and others, does not occur in all species.

Gitler (1964) disputes Nasset's interpretation of his results and claims that the results of Nasset's experiment were due to the rapid digestion and uptake of exogenous protein while endogenous proteins, which are much less digestible, accumulate in the gut lumen. Thus the great preponderance of endogenous amino acids present indicated, not dilution of exogenous protein, but delayed hydrolysis and absorption of the endogenous protein.

The digestibilities of individual amino acids determined in the small intestine in this study were compared with total digestibilities determined by Cho \& Bayley (I970, 1972). Cho \& Bayley (1970) used total collections, but subsequently (1972) used polyethylene glycol as a marker. In both studies, their amino acid analyses were performed by gas-liquid chromatography of amino acid esters. Although there were 
variations in technique and sampling site, the digestibilities of the individual amino acids of SBM in the small intestine in the present study were, in most instances, within $2 \%$ of their estimate of total apparent digestibility. With RSM, however, the agreement between values for digestibility in the small intestine and for total digestion was not as close.

The very large amounts of proline recovered at the ileum, and the fact that for this amino acid the endogenous flow with the protein-free diet was equal to that with the other diets, suggests that proline is secreted in large quantities into the intestine and that resorption by the intestine is small. Horowitz $(1967)$ described the structure of bovine salivary mucin as a repeating unit of serine-glycine-threonine-proline making up half the amino acids in mucin, with glutamic and aspartic acid the most prominent among the other amino acids present. These six were the most abundant of the amino acids in the protein sample from the pigs receiving the protein-free diet (Table 5). Gitler (1964), reviewing a number of experiments, showed that these six amino acids are among those most slowly absorbed from the gut of rats. The high concentrations of these six at the ileum would appear, therefore, to be due to secretion of mucus containing these amino acids and to slow absorption of these amino acids by the intestine. The extremely high concentration of proline relative to other amino acids may be a function of the location of the active transport system for proline, which is independent of the transport system for other amino acids (Ganong, 1969).

The results for the total digestibility of amino acids and their disappearance in the large intestine (Table 7) suggest that there was a net synthesis of arginine, methionine, cystine and tyrosine in the large intestine with both the SBM and RSM diets and of histidine with the SBM diet. There was a net synthesis of all amino acids except proline when the protein-free diet was given, amounting to $3 \mathrm{~g} / \mathrm{d}$, despite the absorption of $\mathrm{N}$ from the large intestine (Table 3). Coelho da Silva, Seeley, Beever, Prescott \& Armstrong (1972) measured the flow of amino acids at the duodenum and ileum in sheep fed on hay diets. They recorded net synthesis in the rumen complex of methionine, cystine, lysine and histidine and in the caecum and colon of arginine, methionine, cystine and tyrosine, with some or all of these diets. This agrees closely with our results for amino acid production by intestinal bacteria.

If it is assumed that disappearance of an amino acid from the small intestine represents its absorption, whereas disappearance from the large intestine represents deamination, and that re-appearance of an amino acid in the faeces represents bacterial synthesis in the large intestine, this experiment suggests a number of discrepancies between the results of digestibility trials and the true absorption of amino acids. Arginine, methionine, cystine and tyrosine may be absorbed in greater quantities than faecal collection results would indicate. Others are absorbed in lesser quantities, with the discrepancy most marked for isoleucine, valine, glutamic acid, aspartic acid, glycine and proline in both SBM and RSM, and also for lysine, threonine and serine in RSM. This latter group includes the six main amino acid constituents of mucin (Horowitz, 1967) which are also the main amino acids found in the endogenous flow with the protein-free diet. It thus appears that large amounts of mucin that are not digested proximal to the ileal fistulas are fermented in the large intestine. 
From digestibility and metabolism trials, it may be assumed that amino acids disappearing during passage through the gut are absorbed, and that urinary $\mathrm{N}$ is derived from deamination processes in the liver. This experiment demonstrates that, for SBM and RSM respectively, $9 \%$ and $16 \%$ of $\mathrm{N}$ absorption, and $4 \%$ and $5 \%$ of amino acid disappearance, may occur as a result of deamination and absorption in the large intestine.

This work was supported by a grant from the Rapeseed Utilization Association of Canada, Winnipeg, Manitoba.

\section{REFEREN CES}

Bayley, H. S., Cho, C. Y. \& Holmes, J. H. G. (1974). Fedn Proc. Fedn Am. Socs exp. Biol. 33, 94.

Bergen, W. G. \& Purser, D. G. (r 968). F. Nutr. 95, 333.

Cho, C. Y. \& Bayley, H. S. (1970). Can. F. Anim. Sci. 50, 521 .

Cho, C. Y. \& Bayley, H. S. (I972). Can. F. Physiol. Pharmac. 5o, 5 I3.

Coelho da Silva, J. F., Seeley, R. C., Beever, D. E., Prescott, J. H. D. \& Armstrong, D. G. (1972). Br. F. Nutr. 28, 357.

Crompton, D. W. T. \& Nesheim, M. C. (1969). F. Nutr. 99, 43 .

Farrell, D. J. \& Johnson, K. A. (1972). Anim. Prod. 14, 209.

Fauconneau, G. \& Michel, M. C. (1970). In Mammalian Protein Metabolism Vol. 4, p. 48 I [H. N. Munro and J. B. Allison, editors]. New York: Academic Press.

Federer, W. T. (1955). Experimental Design, Theory and Application. New York: MacMillan Co.

Ganong, W. F. ( I 969). Review of Medical Physiology. Los Altos, California: Lange Medical Publications.

Gitler, C. (1964). In Mammalian Protein Metabolism Vol. I, p. 35 [H. N. Munro and J. B. Allison, editors]. New York: Academic Press.

Holmes, J. H. G., Bayley, H. S. \& Horney, F. D. (I973). Br. F. Nutr. 30, 401.

Horowitz, M. I. (I967). Handbook of Physiology: Section 6, Alimentary Canal [C. F. Code, editor]. Washington, DC: American Physiological Society.

Nasset, E. S. \& Ju, J. S. (196r). F. Nutr. 74, 46r.

Nasset, E. S., Schwartz, P.\& Weiss, H. V. (I955). F. Nutr. 56, 83 .

Steele, R. G. D. \& Torrie, J. H. (1960). Principles and Procedures of Statistics. New York: McGraw-Hill. Twombly, J. \& Meyer, J. H. (I96I). F. Nutr. 74, 453. 